\title{
メグナ河（バングラデシュ）における橋脚周辺の 河床洗掘に関する長期実測資料に基づく研究

\author{
A STUDY ON LOCAL SCOUR AROUND BRIDGE PIERS IN AN ALLUVIAL RIVER \\ OF MEGHNA IN BANGLADESH BASED ON LONG TERM SURVEY DATA
}

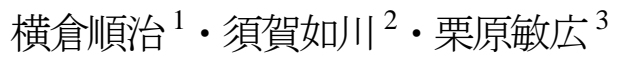 \\ Junji YOKOKURA, Nyosen SUGA and Toshihiro KURIHARA \\ ${ }^{1}$ 正会員 博(工) 東京工業大学特任教授グローバル人材育成推進支援室( 1 152-8550 東京都目黒区大岡山 2-12-1) \\ 2 フェロー会員 特別上級技術者(防琰) 工博 宇都宮大学名誉教授 河相工学研究堂代表 \\ ( ( $276-0023$ 千葉県八千代市勝田台 4-2-4) \\ 3 正会員 (株)ブリツジ・エンジニアリング 技術事業本部 技術部長 元バングラデシュ派遣JCA 専門家(道路・橋梁維持管理) \\ ( ( $655-0047$ 神戸市垂水区東舞子町 4-115)
}

\begin{abstract}
There have been many bridges constructed over alluvial rivers in monsoon regions. However, the characteristics of local scour around bridge piers in such rivers have not been well analyzed. The past researches are all based on the assumption that flow is steady, sediment transport is under a certain equilibrium condition, and that the flood continues only during limited time. On the other hand, actual hydraulic conditions in the rivers are different; flow / sediment transport conditions are unsteady and high water levels continue for several months during wet season, which repeats every year. In this paper, authors clarified the change of the river bed topography around the bridge over Meghna River in Bangladesh, a typical of the rivers, using actual survey data between 1984 and 2007 for 23 years. The result shows that the local scouring progressed for 16 years after its construction in 1991. The values of scoured depth are larger than those estimated with the methods proposed by past papers. The facts found in this research are practically important and will contribute to planning and maintenance of bridges over identical rivers.
\end{abstract}

Key Words: monsoon regions, alluvial rivers, local scour around bridge piers, long term survey data, channel stability

\section{1.はじめに}

メグナ橋はバングラデシュの主都ダッカの南東約 $30 \mathrm{~km}$, 国 道 1 号線がメグナ河を渡河する地点に, 日本の ODA により 1991 年に建設された全長 $930 \mathrm{~m} の$ PC 箱析橋である. 同橋の 位置を図-1, 概観を図-2, 調査·工事履歴と構造諸元を表-1 に 示した. その後 1997 年の JICAによる調査で, 左岸寄りの橋脚 周りで河床浸食が著しく, 1984 年の調査時より最大で $16.6 \mathrm{~m}$ 低 下し，これらの橋脚の安全性は限界状態にあることが明らかと なった ${ }^{11} .2007$ 年のバングラデシュ道路局による深浅測量では, 同橋脚下流で河床低下が一層進行していることが判明した ${ }^{2)}$.

橋脚周りの局所洗掘については, これまで多くの研究が行

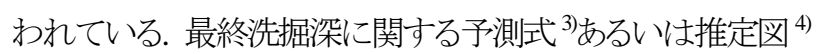
が提案されており, 数值シュミレーションモデルの開発も行わ れている ${ }^{5}$. これら既往研究の水理模型実験では, 流れの継 続はある一定の時間内に限定される. 一方メグナ河では表-2 のように, 雨季の間約5力月にわたって大きな流量, 水深と流
速が継続し, これが毎年繰り返される. 雨季と乾季に約 $5 \mathrm{~m}$ の 水位差が生じるが, 先鋭なピークを持つ洪水は発生しない. こ のように既存研究と実河川とでは水理的条件が異なるので, 従来提案された予測式が適用できないと考えられる. 須賀ら の推定図については, 水深 $\mathrm{h}_{0}$ が大なので, $\mathrm{h}_{0} / \mathrm{dm}(\mathrm{dm}$ : $0.1 \sim 0.2 \mathrm{~mm})^{1)}$ と $\mathrm{h}_{0} / \mathrm{D}(\mathrm{D}$ : 橋却の幅(径)) は過大となり, 適用外 となる. さらに底質が微細砂とシル卜を含む材料であるために 河道が不安定であり, 橋脚以外に湾曲流による影響を無視で きないの．また，近傍の河川構造物による影響も受ける7》。

横倉らはこのような実河川に関し, 1984 97 年の 13年間にお けるメグナ橋周辺の河床低下の実態を明らかにした ${ }^{8)}$.この論 文を第1 報と位置付け，本論文は第2 報として更に1997 2007 の 10 年分を追加, メグナ橋周辺河床の変動現象を実測資料 に基づいて解明した. まず2007年の道路局による深浅測量結 果について, 河床・河岸の状況を整理し, 1997 年 2007 年の変 


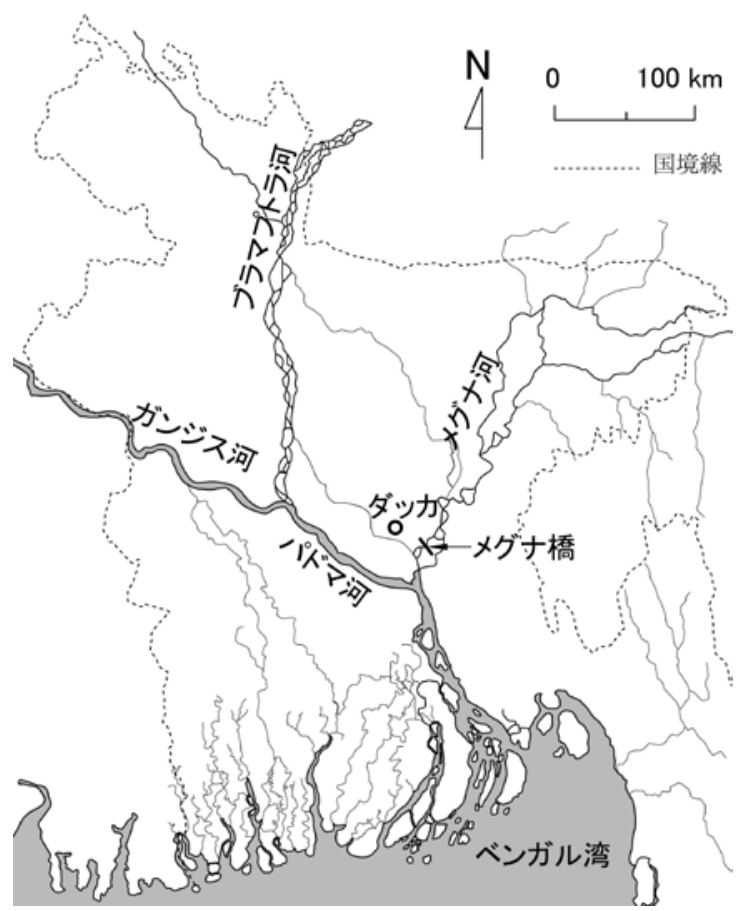

図-1 メグナ橋位置図

表-1 メグナ橋の調査·工事履歴と構造諸元

\begin{tabular}{|l|l|}
\hline 1984 85 & 橋梁建設のための JCAによる調査 \\
\hline 1987 91 & 日本の資金協力による建設工事 (P1 P10 周り捨石工を含む) \\
\hline 1994 & 上流左岸での篭工による護岸建設（日本の資金協力） \\
\hline 1997 & 橋梁周辺河床対策のための JICA による調査 \\
\hline 1998 & P7 P9 周りと護岸前面への捨石工 (日本の資金協力) \\
\hline 2007 & バングラデシュ道路局による橋梁周辺河床での深浅測量 \\
\hline 構造諸元 & 13 径間, 現場打 RC杭(L=40 48m@P1 P10), 橋脚幅 D=3.2m \\
\hline
\end{tabular}

化を解析した.そして 1984 2007 年の 23 年間における橋梁周 辺での河床低下の特徵に関して検討・考察した. その結果， 洗掘は橋梁完成以来 16 年間継続しており, その規模は従来 の予測手法により得られる值を超えていること, そして橋脚周り に護床工として敷設した捨石が，その部分の河床洗掘に抵抗 して杭の露出を防いでいることなどが明らかとなった。

メグナ川のような大陸沖積河川は, アジアモンスーン地帯だ けでなく他にも多く存在するので，その実態の把握は，類似河 川での長大橋計画と維持管理に有用であり, 実務遂行上重要 な課題である.

\section{2007 年の深浅測量}

2007 年 10 月 28 日〜 11 月 1 日の間, バングラデシュの運輸 省道路局 (Roads and Highways Department, Ministry of Communications) はメグナ橋周辺の深浅測量を行った. 測量 では音響測深器を搭載したボートが，あらかじめ設定された測 線を移動した. 測線の位置は以下のようであり, これを図-3に 示した.

a. 河川横断測量

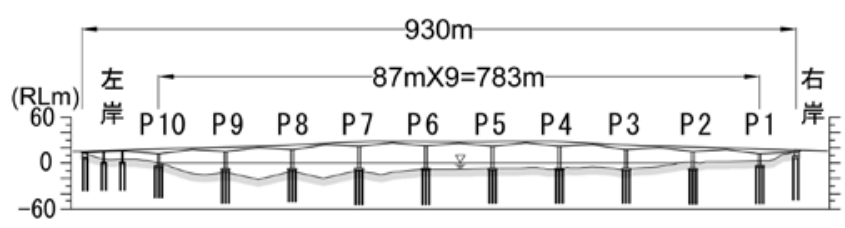

注）図中左側, RLm とは,「バ」国の公共事業で使用される標高表示.

図-2 メグナ橋概観図

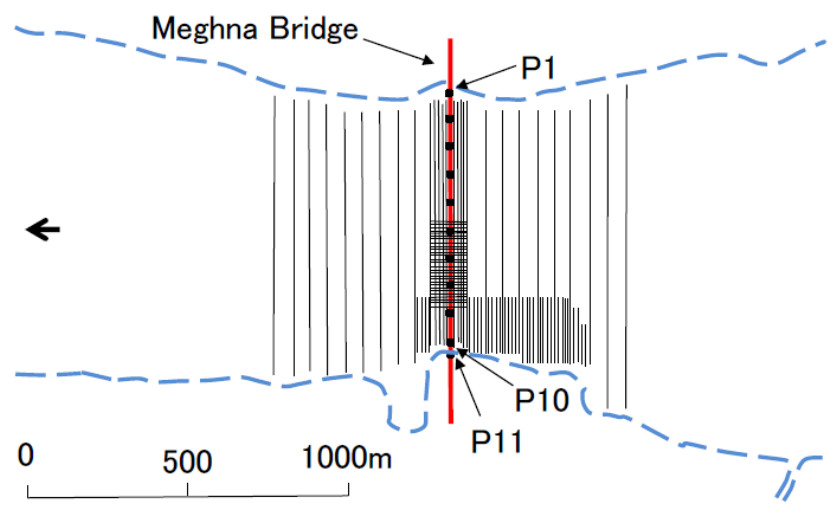

図-3 2007 年の深浅測量における測線位置図

表-2 メグナ橋地点での水理条件

\begin{tabular}{|l|c|c|c|}
\hline & 雨季 : 6 10月 & 乾季 : 11 5月 & \multicolumn{1}{|c|}{ 備考 } \\
\hline 流量 $\left(\mathrm{m}^{3} / \mathrm{s}\right)$ & $0.3 \sim 1.3$ 万 & 数百 & 河床勾配 $1 / 10$ 万 \\
\hline 水位 $(\mathrm{RLm})$ & $2 \sim 6$ & $1 \sim 2$ & 約 $1 \mathrm{~m} /$ 月で変化 \\
\hline 流速 $(\mathrm{m} / \mathrm{s})$ & $0.3 \sim 1.3$ & $0.2 \sim 0.5$ & 潮位の影響あり \\
\hline
\end{tabular}

1) 橋軸の下流 $50 \mathrm{~m}$ 上流 $50 \mathrm{~m}: 10 \mathrm{~m}$ ピッチで橋軸上下流各 5 本および橋軸沿い 1 本, 合計 11 本の左右岸を結ぶ横断線

2) 橋軸下流 $100 \mathrm{~m} \sim 500 \mathrm{~m}$ ，上流 $100 \mathrm{~m} \sim 500 \mathrm{~m}: 50 \mathrm{~m}$ ピツチで 上下流各 9 本，合計 18 本の左右岸を結ぶ横断線.

b. 河川絎断測量

P6 P9 を結ぶ, 橋軸に沿った延長 270mの線上において, $10 \mathrm{~m}$ ピッチで, 橋軸直角に上下流へそれぞれ $\mathrm{L}=50 \mathrm{~m} の$ 縦断 線合計 28 本を延伸, 1 本の縦断線の長さは上下流合計 $100 \mathrm{~m}$. c. 護岸前面に形成された洗掘孔の深浅測量

P11 から橋軸に対して直角に，上下流双方向に引かれた直 線を基準線とし, 橋軸の下流 $100 \mathrm{~m}$ ～上流 $400 \mathrm{~m}$, 全長 $500 \mathrm{~m}$

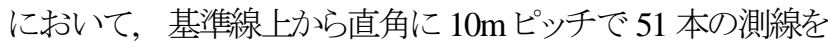
設置. 各測線は河岸〜護岸前面の洗掘孔をカバーできる範囲 で，長さは145 220m.

\subsection{4 年から 2007 年における河川地形の変化}

\section{(1) 護岸前面の洗掘孔}

護岸前面に形成された深掘れは, 1984 年の調査では, 最深 点の標高は約 RL-18m²)であって, 既存護岸の上流端付近に 存在した旧フェリ一突堤に起因する局所洗掘と考えられた. 既 存護岸が完成した 1994 年以降も, 河道の中に凸状に張り出た 護岸形状に影響されて次第に深くなり，平面的にも広がり，橋 


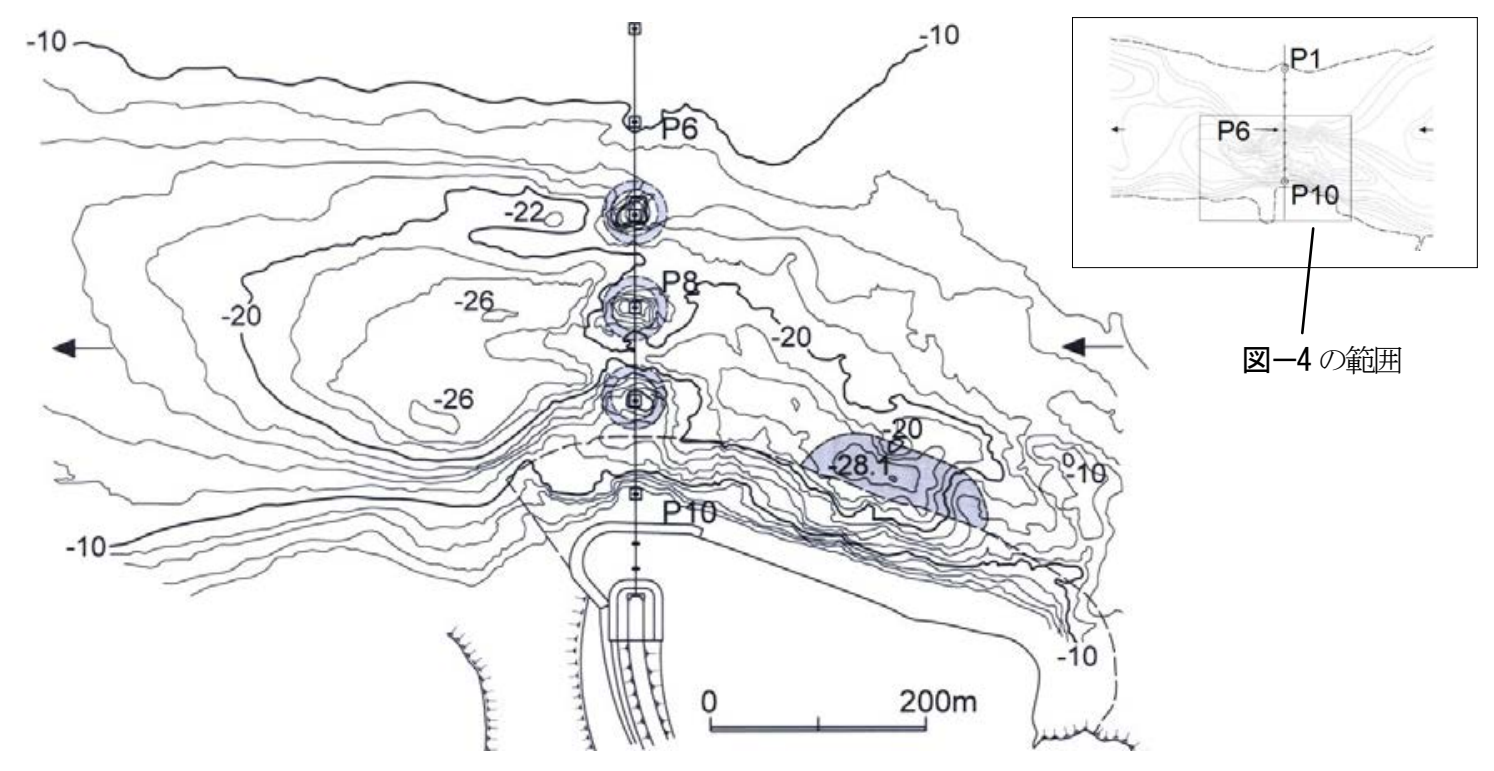

図-4 橋梁周辺河床(2007 年)

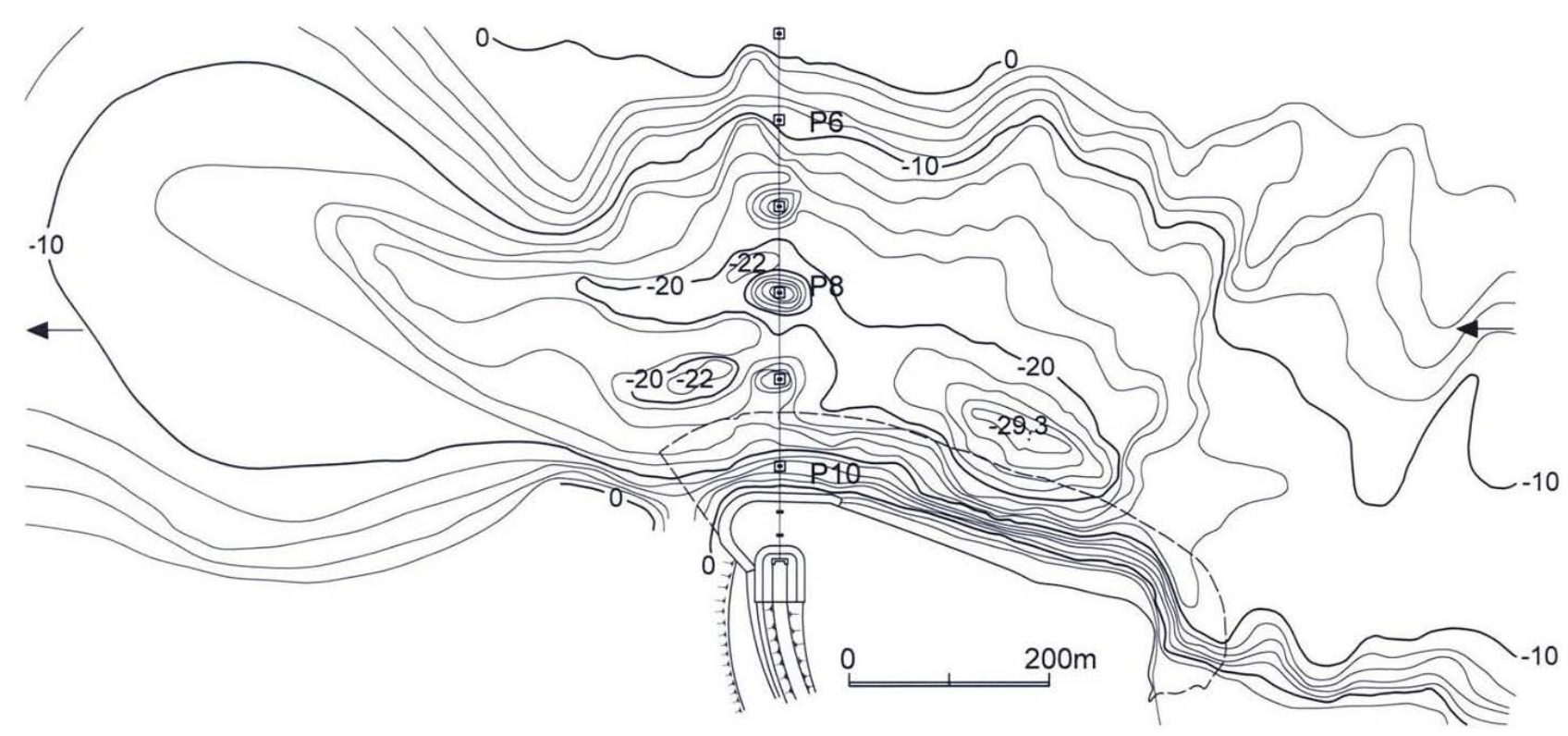

図-5 橋梁周辺河床(1997 年)

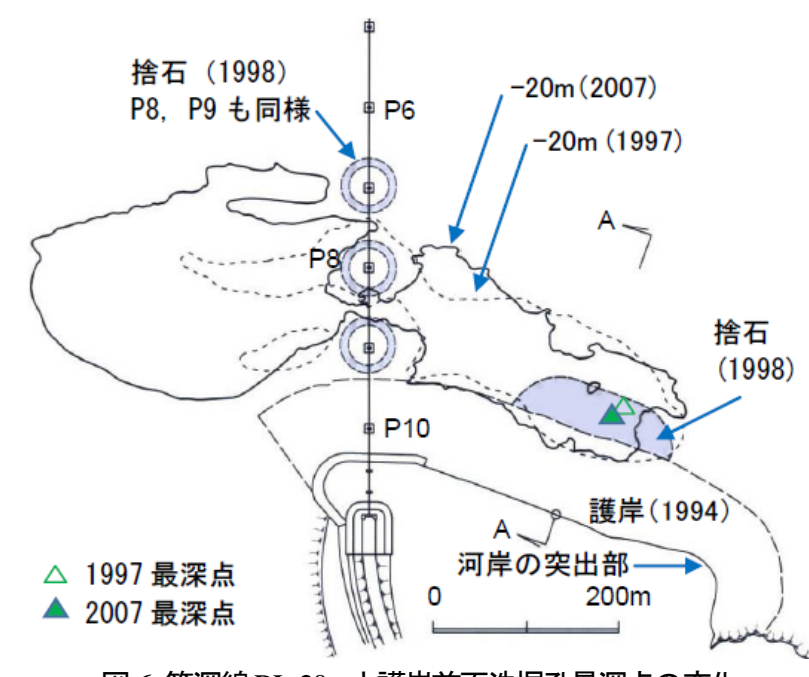

図-6 等深線 RL-20mと護岸前面洗掘孔最深点の変化

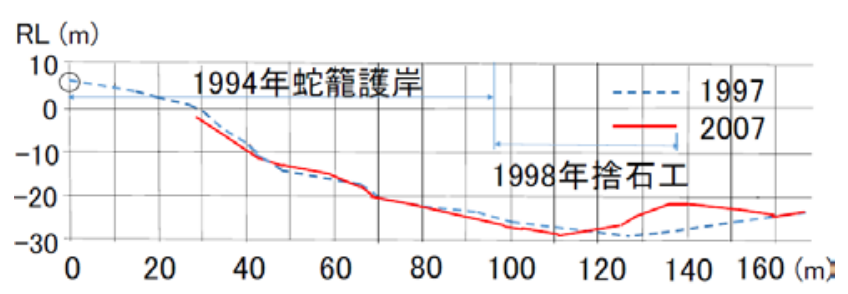

図-7 護岸前面洗掘孔の横断図(A-A 断面)

脚周りの河床低下に影響すると推定された ${ }^{8)} .1997$ 年には最深 部標高は RL-29.3m²) となった. 図-4 と図-5に, 2007 年と 1997 年 の等深線図を示した. 図-6には, 図-4 と図-5 での-20m の 等深線を示した. 図-7には, 図-6のA-A断面を示した. これら の図から読み取れる事柄は, 以下のようにまとめられる. 1) 最深点の河床高は, 1984 年 1997 年の 13 年間で $11.3 m$ 低 
表-3 護岸前面, 橋脚間, および橋脚下流域における河床変動（RLm）

\begin{tabular}{|l|l|l|l|l|l|l|l|l|l|l|l|}
\hline & 護岸前面 & P9 P8 & P8 P7 & P7 P6 & P6 P5 & P5 P4 & P4 P3 & P3 P2 & P9下流 & P8下流 & P7下流 \\
\hline $1997.4:$ 乾季末 & -29.3 & -20.5 & -21.8 & -19.2 & -1.8 & -1.1 & -0.6 & -0.9 & -22.0 & -20.0 & -19.0 \\
\hline $1998.10:$ 雨季末 & -29.0 & -20.0 & -20.0 & -17.0 & -4.0 & -1.9 & -2.0 & -0.8 & -19.0 & -22.0 & -20.0 \\
\hline $2007.10:$ 雨季末 & -28.1 & -20.7 & -20.6 & -15.2 & -8.1 & -5.5 & -4.4 & -4.7 & -26.0 & -26.0 & -22.0 \\
\hline
\end{tabular}

注) 1998.10 の数值は参考文献 8)の図-15, 図-20より読み取った.

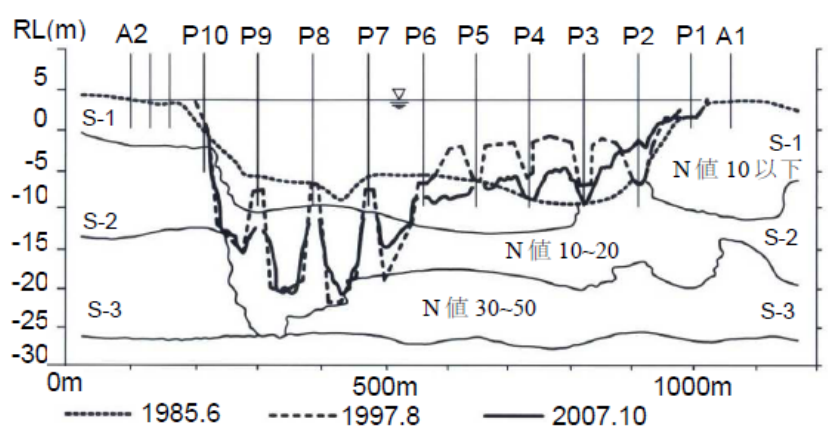

注）橋脚を示す棒線下端はフーチング底面の位置. P2 P10の橋脚フ ーチング底面の標高は RD-9.5m. フーチングの厚夕は $2.2 \mathrm{~m}$.

図-8 橋軸横断方向の河床高変化

表-4 橋脚周りの捨石工の頂点標高と法勾配(角度)の変化

\begin{tabular}{|c|l|l|l|l|l|l|l|}
\hline \multicolumn{2}{|c|}{} & \multicolumn{2}{|c|}{ P9 } & \multicolumn{2}{c|}{ P8 } & \multicolumn{2}{c|}{ P7 } \\
\hline \multicolumn{2}{|c|}{} & 下流 & 上流 & 下流 & 上流 & 下流 & 上流 \\
\hline \multirow{2}{*}{$\begin{array}{c}\text { 頁点標高 } \\
\text { (RLm) }\end{array}$} & 1997 & -8.5 & -8.5 & -11.2 & -14.3 & -9.0 & -8.8 \\
\cline { 2 - 8 } & 2007 & -10.3 & -8.8 & -12.2 & -11.4 & -10.2 & -8.9 \\
\hline 法勾配 & 1997 & $30^{\circ}$ & $20^{\circ}$ & $40^{\circ}$ & $35^{\circ}$ & $25^{\circ}$ & $25^{\circ}$ \\
\cline { 2 - 8 } & 2007 & $25^{\circ}$ & $21^{\circ}$ & $33^{\circ}$ & $31^{\circ}$ & $16^{\circ}$ & $11^{\circ}$ \\
\hline
\end{tabular}

注1) フーチング底面高は RL-9.5. その下に厚さ $1.5 \mathrm{~m}$ の捨コンあり.

注2） 1997 年の測量では, フーチング上下流面で, それぞれ最も頂 点が低下していると潜水夫が目視確認した点で, フーチング底面また は上面との差を計測した. P8 上流の頂点標高に関し, 1997 年が 2007 年より低いのは, 計測した点の不一致が推定される.

下した.一方1997年 2007年の10年間では1.2m浅くなった. 急激な洗掘があったが，それ以降は落ち着いたといえる.

2) 1997 年 4 月乾季末と 1998 年雨季末の数值を比較すると, 顕 著な季節的変化は見られない(表-3).乾季に埋まらないの は微細砂濃度が低いことが一因として推定される。

3) 図-6 と図-7 より, 洗掘孔内部では, 河心側で堆積が進んだ 部分が認められる.

4) P8 上流付近を除けば, 平面的形状に両年の間で大きな変 化は見られず, また最深部の位置は概ね一致している.

\section{(2) 橋軸治い}

図-8において, 1985 年, 1997 年, および 2007 年における橋 軸沿いの横断測量結果を比較した. 表-3 に橋脚間の河床の 変化を示した.

1) 1997 年乾季末と1998年雨季末の数值を比較すると, 季節的 変化と思われる部分がある. この点を考慮しても 10 年間をと おしての変化として, 以下 2),3)があげられる.
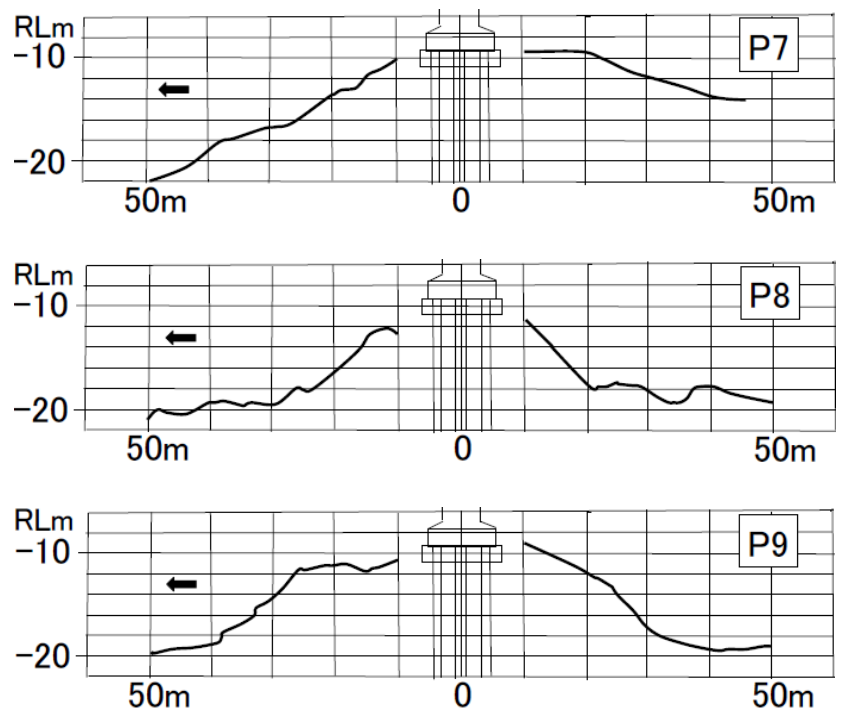

図-9 P7, P8, P9 の上下流それぞれ 50m の河床縦断図(2007 年)

2) 河心より左岸側, P7 P9 の橋脚間の河床では, 1985 1997 に 約14m といら大な河床低下が見られたが, 1997 2007年で はその規模での低下現象は終息した。

3) 河心より右岸側, P2 P6 では, 1997 2007 年での河床の低下 量が大きい. 各橋脚間での低下量は 3.8m 6.3m であった.

\section{(3) 橋脚周り}

1) 建設時に橋脚周り半径 $20 \mathrm{~m}$ の範囲に厚さ $2 \mathrm{~m}$ で玉石を敷設 した護床工は，周辺河床低下に伴って変形し，1997 年調查 にお゙けるP7 P9の水中写真では, 橋脚フーチング以下の基 礎構造を玉石が円錐状に包んでいる ${ }^{1)}$. 図-9に2007年にお ける P7 P9 の上下流 50m の縦断図 ${ }^{2)}$ を示した. 同図と図-8 から, 2007 年にも同様な状態にあると考えられる.

2) 表-4に円錐の頂点標高と法勾配の変化 ${ }^{10)}$ を示した. P7 とP9 では, 1997 年には頂点がフーチング底面より上にあったが, 2007 年には同底面より下がった. P8 では, 1997 年には既に 上下流とも頂点は同底面より下にある. これら 3 橋脚では, 次第に円錐頂点が下がり，法勾配も緩やかになった。

3) P8 上流側に局所洗掘が発達した(図-4 図-6).

4) P7 右岸側の側面に存在した局所洗掘は浅くなった (同上).

\section{(4) 橋梁下流}

1) 図-4 と図-5 の比較では, P7, P8, P9 それぞれの下流に存 在する洗掘孔の深さが増し, 最深部の位置が下流に移動し ている. 図-6 では，両年の-20m 等深線の比較から, 洗掘孔 は全体的に下流に移動してる, 各洗掘孔の最深点の深さ 


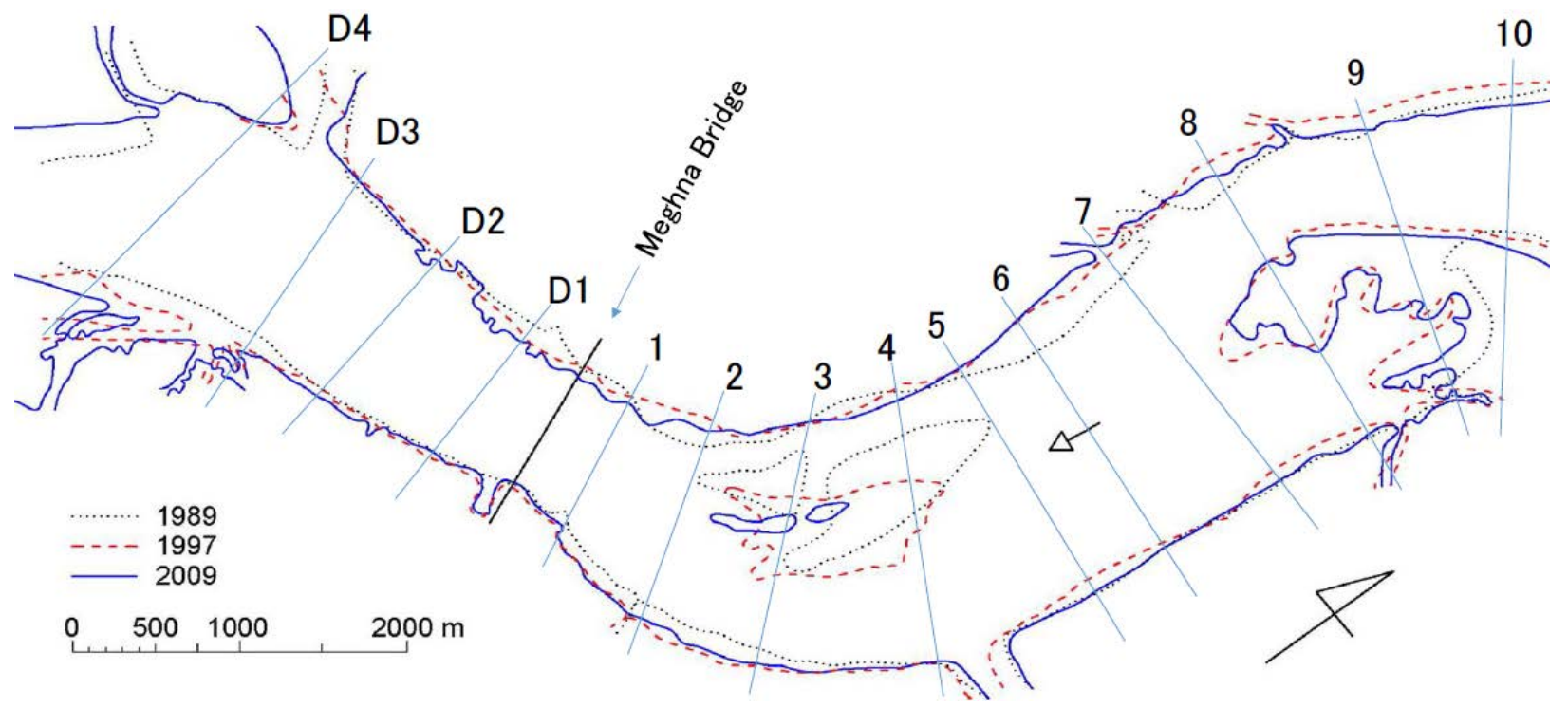

図-10 河岸線の経年変化

表-5 メグナ橋周辺河床における 1985 年からの低下量

\begin{tabular}{|c|c|c|c|c|c|c|c|c|c|}
\hline \multirow[t]{2}{*}{ 洗掘 位置 } & \multicolumn{3}{|c|}{ 河床高 } & \multicolumn{2}{|c|}{$\begin{array}{l}\text { 護岸前面洗掘孔から橋脚 } \\
\text { に達寸る 等深線 (RLm) }\end{array}$} & \multicolumn{2}{|c|}{ 橋脚による洗掘量 $(\mathrm{m})$} & \multicolumn{2}{|c|}{ 総河床低下量 (m) } \\
\hline & (1) 1985 & (2) 1997 & (3) 2007 & (4) 1997 & (5) 2007 & 1997:(4)-(2) & 2007:(5)-(3) & 1997:(1)-(2) & 2007:(1)-(3) \\
\hline P7 8 間 & -8.4 & -22 & -20.7 & -18 & -18 & 4 & 2.7 & 13.6 & 12.3 \\
\hline P8 9 間 & -6.3 & -20.4 & -20.3 & -19 & -19 & 1.4 & 1.3 & 14.1 & 14.0 \\
\hline P7 下流 & -5.5 & -18 & -22 & -15 & -16 & 3 & 6 & 12.5 & 16.5 \\
\hline P8 下流 & -7 & -22 & -26 & -18 & -18 & 4 & 8 & 15 & 19 \\
\hline P9下流 & -5.4 & -22 & -26 & -16 & -16 & 6 & 10 & 16.6 & 20.6 \\
\hline
\end{tabular}

の変化を表-3 に整理した. 10 年間で 3 6m 深くなった.

2) 表-3 で季節的変化と思われる数值を考慮しても，下流域は 低下傾向を示しているといえる. 各洗掘孔は繋がって, 一つ の大きな洗掘孔に発達した.

\section{(5) 橋梁上下流の湾曲形状}

図-10 に, メグナ橋下流 $2.8 \mathrm{~km} \sim$ 上流 $6.7 \mathrm{~km}$, 合計約 $9.5 \mathrm{~km}$ の河道区間に関し, 1989 年, 1997 年, および 2009 年の平面形 状を示した. なお同区間の地形測量は1997年を最後に実施さ れていないので，2009年は衛星写真 C 2009 Google の河岸 線をトレースしたものである. 橋梁周辺の河床低下に直接影響 を及ぼすと考えられる上流左岸側の湾曲外側の河岸では, 橋 梁力ら測線 4 まで河岸の後退はない.

\section{4. 考察}

（1）橋脚周辺における河床低下の原因:

橋脚周辺河床の低下の原因として, 河川の湾曲流, 護岸前 面の洗掘孔の影響, および橋脚による局所洗掘,の 3 種類が 考えられ, 横倉らは同 3 種類の原因別洗掘量を, 線形和を前 提として等深線から第一近似として読み取った ${ }^{8)}$.

1997年迄の護岸前面の河床低下の原因としては, 河岸の突 出した形状のほか湾曲流の影響も想定される. しかし同年以 降には護岸前面の洗掘孔の形状がほとんど変化していないの
で, これらの影響は落ち着いたと思われる. その要因として, 1998 年捨石工の効果, 護岸上流の河岸線が後退せず突出部 の形状に変化がなかったことのほか，湾曲流による影響の沈 静化, 供給土砂の現象に顕著な変化がなかったことなどが推 定される.

このことを前提とすれば, 2007年に見られたP7 P9下流側の 河床低下は，主に各橋脚とそのフーチング以下の円錐形状の 護床工に影響されて発達したと考えられる ${ }^{11)}$, 12). また P8 上流 の局所洗掘の拡大は, 流れが橋脚と円錐形状の護床工に遮ら れて上流側から側面に回り込むことにより拡大したと推測した.

1997 年以降測線 6 4 にか忊て右岸が比較的安定しており (図-10), 流れが直線化して中州右岸側水路が拡大したことが 推測される. このことは河心から右岸寄り橋脚周りの河床低下， 湾曲左岸側の流勢縮小, 護岸前面の洗掘の沈静化に影響し たと推定される. 河心から左岸寄り橋脚周りの河床低下速度の 減少の一因としては, $\mathrm{N}$ 值の大きな地層の露出も推定される.

(2) 橋脚の影響による河床洗掘深の推定:

湾曲流と供給土砂量の変化は川幅スケールの現象に影響 を及ぼすと考えられる. しかし今回原因別河床低下量としては, 橋梁周辺での測量結果を用いて, 橋脚による洗掘深, すなわ ち橋脚スケールの局所的現象についてのみ検討して結果を 表-5 に整理した. その值は「護岸前面洗掘孔から各橋脚に達 する等深線一河床高」により読み取った. 
表-6 既存予測式より求めた橋脚による局所洗掘の深さ

\begin{tabular}{|l|c|l|c|}
\hline \multicolumn{1}{|c|}{ Author } & 洗掘深さ & \multicolumn{1}{c|}{ Author } & 洗掘深さ \\
\hline Tarapore & 4.3 & Neil & 7.5 \\
\hline Larras & 4.8 & Qureshi & 3.4 \\
\hline Breusers & 4.5 & 国鉄 & 5.1 \\
\hline
\end{tabular}

注1） $\mathrm{h}_{0}=14 \mathrm{~m}, \mathrm{v}=1 \mathrm{~m} / \mathrm{s}, \mathrm{dm}=0.2 \mathrm{~mm}, \mathrm{D}=3.2 \mathrm{~m}$ (橋脚の幅)

注2） $h_{0}$ は橋脚付近の平均水深. 雨季の平均的水位RL5m $と$, 湾曲流 の影響と考えられる1997 年河床高 RL-9m との差とした ${ }^{8}$.

(3) 橋梁下流での河床洗掘の進展:

P7 P9 の橋脚下流に形成された洗掘孔は, 橋梁完成以来継 続的に拡大している. 局所洗掘は通常橋脚前面で最大值とな り，最深部は橋脚側面に沿って伸び，その深さは次第に浅く なる. 掃流力の低下寸る橋脚下流部では，一般に洗掘される ことは稀であるが 3)，ここではそれと異なり，橋脚下流に形成さ

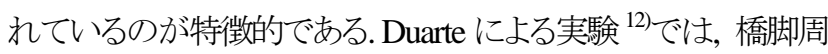
りの護床工として河床レベルより上に捨石を積み上げた場合， 下流側に洗掘孔が形成される. メグナ橋でも捨石が河床から 円錐状に立ち上がっておう，下流の洗掘孔が同様な条件下で 形成されたと思われる. わずかな擾乱が常に河床に影響して， $0.01 \mathrm{~mm}$ 以下の河床材料が流砂しして流失することが推定され る. P8 P9 下流河床で, RL-15m以下の地層にN值10 20 の S-2 層, または N 值30 50 の S-3 層が存在すると推測されるが(図 -8), 洗掘されているのは S-2 層と考えられる.

(4) 既存式による予測值と実際の洗掘との比較:

橋脚による局所洗掘の深さを, 既存の予測式より求めて表-6 に整理した ${ }^{3)}$. ただし, Andru, Laursen の式および須賀らによる 推定図は適用範囲外であるため除外した. 2007 年における P8 とP9下流の, 橋脚によると推定される洗掘量(表-5)は，表-6中 のすべての予測值を越えている.

(5) 橋脚周りの捨石工の効果:

橋脚の杭の構造計算は, 計画河床高を RL-22mとして行わ れているので ${ }^{1)}$, P7 P9 周辺の河床低下状況から, 1997 年より 引き続き 2007 年時点でも, これらの橋脚は構造上の安全に注 意を払うべき状態にあると考えられる. このような状況にあって, 建設時と 1998 年に行われた捨石工が橋脚周りの河床洗掘速 度を低下させ，基礎構造を円錐状に包んで，杭がむき出しに なることを防いでいる.

\section{5. まとめ}

モンスーン地域の大陸沖積河川の代表的事例であるバング ラデシュのメグナ河に建設されたメグナ橋において, 計画段 階から 23 年間にわたって蓄積された実測值を用いて, 橋梁周 辺河床の変化の実態を明らかにした. 結論を以下にまとめた.

1) 橋脚周りの局所洗掘は長期間継続する. 湾曲外側の橋脚 では, 建設 16 年後においても洗掘が進行している. N 值に よる程度差はあるが, Dm=0.01mm 以下の材料が河床に存 在する限り, 橋脚による局所洗掘は継続すると推定される.

2) 橋脚下流に形成された洗掘孔は, 橋脚上流あるいは側面と
比較して規模が大きく, 従来の研究成果によって得られる予 測值を超えている. 計画河床高の検討にあたっては, この 点に留意する必要がある.また架橋位置の選定に際しては, 橋梁の下流側河床の安全性に注意する必要がある.

3) 橋脚周辺に敷設された捨石は, 周辺河床の低下に伴って 円錐形に変化して橋脚フーチング以下の杭の露出を防い でおり, 護床工としての機能を果たしている.

4) モンスーン地域の沖積河川では，既に多くの長大橋が建 設されている. これらの実河川と既往研究とでは水理条件 が異なり，研究の成果をそのまま適用することができないと 考えられる. したがって, 実際に起こっている現象の解明は 重要であり, 本論文は実務的に貴重な事例研究となる. 同 様な水理特性を有する河川に建設された他の橋梁におい てもモニタリングを行ってデータを集積し, 複数の研究成果 を体系化することが今後の課題である.

\section{参考文献}

1) 国際協力事業団:バングラデシュ共和国メグナ橋護岸改修計画基 本設計調査報告書, 写真p.10,pp.7-8 7-11, 図 5-33 図 5-43, 1998

2) Toll Operation and Maintenance of Meghna Bridge and Associated Works, Roads and Highways Department, Ministry of Communications: River Training Works, Bathymetric Survey Report, Report No. BR-MG-H1-004, BROMAS-JV, Oct 28 to Nov 01, 2007

3) 宇多高明, 高橋晃, 伊藤克雄: 治水から見た橋脚問題に関する検 討, 土木研究所資料第 3225 号, PP.13 17, 1993

4) 須賀堯三, 西田祥文, 高橋晃, 坂野章:橋脚による局所洗掘深の予 測と対策に関する水理的検討, 土木研究所資料第 1797 号, pp.13 14, 41 49, 1982

5) 福岡捷二, 富田邦裕, 堀田哲夫・宮川朝浩:橋脚まわりの局所洗掘 推定のための実用的数值シミュレーションの開発, 土木学会論文集 No.497/II-28, pp.71 79, 1994.8

6) 長田信寿, 細田尚, 村本嘉雄: 河岸浸食を伴亏河道変動の特性とそ の数值解析法に関する研究, 土木学会論文集 No. 621/II-47, pp. 23-39, 1999

7) 村本嘉雄, 藤田裕一郎, 河内友一:メグナ河下流部における洪水 流之河道変動, 京都大学防災研究所年報, 第 37 号 B-2, pp.421-439, 1994

8) 横倉順治・須賀如川:開発途上国の未改修・不安定河川の架橋計 画に関する河川工学的考察, 土木学会論文集 No.733/II-63, p.37 56, 2003

9) 国際協力事業団:バングラデシュ人民共和国メグナ河護岸対策計 画基本設計調査報告書, pp.51, 1992

10） 1)の資料編,pp.資 3-1 3-10, p.3-17, 1998

11) 宇民正: 橋脚後流域の流れのパターンについて, 京大防災研究 所年報, 第17 号B, pp.701 714, 1974

12) Duarte, C. A., Sainz, J. A.: Riprap at bridge piers, J. Hydraulic Research, IAHR, Vol. 37, No. 3, pp. 291 307, 1999

(2013.9.30 受付) 